\title{
Protean power as a plea for an open social ontology, non-efficient causal explanations, and cautious political practice
}

\author{
Stefano Guzzini ${ }^{1,2,3}$ (D) \\ ${ }^{1}$ Uppsala University, Uppsala, Sweden, ${ }^{2}$ Pontifícia Universidade Católica do Rio de Janeiro (PUC-Rio), Rio \\ de Janeiro, Brazil and ${ }^{3}$ Danish Institute for International Studies, Copenhagen, Denmark \\ Corresponding author. E-mail: sgu@diis.dk
}

(Received 19 June 2019; revised 4 December 2019; accepted 30 December 2019; first published online 17 August 2020)

\begin{abstract}
This paper probes the attempt to use power analysis to link three domains: ontology, explanation, and the strategy of political actors. It shows how Katzenstein and Seybert develop an open social ontology that serves as the backdrop for explanations that need to be causal but indeterminate, and a cautious political practice. It exposes tensions in two important links. First, the open ontology becomes retranslated as an explanatory cause. Second, the call for being cautious because of 'unknown unknowns' may just as well invite strategies of doubling down in control power.
\end{abstract}

Keywords: power analysis; causation in the social sciences; US foreign policy

Whenever we look for new or revised concepts, we find our existing terms insufficient to capture some or other parts of reality. Research is driven not so much by the attempt to improve our answers to existing questions as by unease or frustration about the way the questions are asked in the first place - more precisely, about the ways our existing terms frame the problematics. Scholars turn to re-conceptualizations when they are interested in the constitutive function of theories, that is, in establishing those 'analytical lenses' that constitute the very conditions for the possibility of knowledge. Reality strikes back at our conceptions of the world, but in the terms in which we ask questions and decipher responses.

Making such conceptualizations is a highly empirically driven theoretical enterprise. Yet, its aim does not consist of generalizations informed by empirical regularities. Instead, the link from empirics to theory is made through abstraction. Concepts serve as epistemic tools with which to capture significant components of the real world and its explanation. By specifying a better or different way to capture the nature of things, such conceptualizations necessarily have an ontological component. ${ }^{1}$ They select and

\footnotetext{
${ }^{1}$ Guzzini 2013a.

(c) The Author(s), 2020. Published by Cambridge University Press. This is an Open Access article, distributed under the terms of the Creative Commons Attribution licence (http://creativecommons.org/licenses/by/4.0/), which permits unrestricted re-use, distribution, and reproduction in any medium, provided the original work is properly cited.
} 
stylize part of reality, as with ideal types. Rather than looking for similarities and regularities, these concepts, once embedded in wider social theories, guide us to make relevant distinctions, as, for instance, in the innumerable qualifications made to the Weberian ideal type of the modern state. They inform our understanding of the world and, at least for some significant concepts, also our action in it, since we have come to see the world differently. ${ }^{2}$

Protean Power is one such attempt to lead our understanding of world politics to new grounds. Although Katzenstein and Seybert know that any such reconceptualization ultimately needs some coherent theoretical embedding, ${ }^{3}$ they try to remain agnostic about it so as not to risk premature closure. They mobilize rich and wide cases from which their conceptual abstractions can then feed into the systematizing grand theorizing of the kind that has recently seen a remarkably rich renewal. ${ }^{4}$

In this regard, the choice of 'power' comes in handy. The concept of power is crucially connected to, and in turn connects, three different domains. In political theory, power often invokes autonomy (hence freedom) and government in terms of political order (and the common good). In explanatory theory, power has been likened to causal relations and dispositions (hence agency and responsibility) and rule or domination (hence the origins and nature of the social order). In political practice, it mobilizes an understanding of politics as the 'art of the possible. ${ }^{5}$ As if that was not enough, power can be a performative connected to our understanding of politics. In our political discourse, attributing power means attributing responsibility and prompts the need to justify both action and non-action. ${ }^{6}$ Indeed, the very definition of power is a political issue among practitioners and not just observers. The definition of international hierarchies in terms of one understanding of power rather than another has major implications for the constitution of the international order, as when, for instance, it affects what counts as legitimate rule and necessary agency. If practitioners were to agree with Joseph Nye's soft power ${ }^{7}$ as a depiction of the nature of hierarchy and a model of legitimate foreign-policy aims, world politics would look different. This is intentional on his part, his redefinition (and his plea for it in places such as China and back home in the USA) specifying attempts to influence foreign policy and the world order. With respect to its close relationship with the understanding of politics, there is hence also a (power) politics of defining power, ${ }^{8}$ as Daniel Frei argued half a century ago. ${ }^{9}$ Any re-conceptualization of power reverberates with the wider and fundamental themes of International Relations (IR) theory.

The presence of these various purposes and sites, with their different logics, poses considerable intellectual and political problems and prompts tautologies

\footnotetext{
${ }^{2}$ Connolly 1974 .

${ }^{3}$ Seybert and Katzenstein 2018, 9, footnote 35, Katzenstein and Seybert 2018a, 292.

${ }^{4}$ See e.g. Adler 2019, Albert 2016, Kratochwil 2018, Qin 2018, Weber 2016, Wendt 2015.

${ }^{5}$ Guzzini 2013b.

${ }^{6}$ For this argument as applied to IR, see Guzzini 2005, developing an argument of Connolly 1974 and Lukes 1974.

${ }^{7}$ Nye 2004, 2007.

${ }^{8}$ Guzzini 2009.

${ }^{9}$ Frei 1969.
} 
and contradictions. For instance, the same realists who would insist on the centrality of power maximization and balancing - both mechanisms dependent on its measurability for a falsifiable explanation - are at pains to caution practitioners that there is no real measure of power. ${ }^{10}$ And as they typically make the two arguments in the same book, ${ }^{11}$ the practical and explanatory domains collide. Realist prudence asks for a different analysis of power than realist explanations. Given these problems, the temptation is great not to bother and simply focus on one domain as if the other did not matter (and as if the two were not linked), as a great deal of the analysis of power in IR did by reducing power to a factor or variable. Alternatively, one can propose typologies which seem to cover wider domains, but turn out to be mere taxonomies based on possibly incommensurable underlying theories and meta-theories, ${ }^{12}$ instead of aligning the underlying theories to consistently integrate a variety of understandings of power. ${ }^{13}$

It is one of the truly great merits of Protean Power that it does not avoid the difficulties of addressing questions of ontology, explanation, and political practice at the same time, and to insist that they are related and need to be re-thought together. In the book, protean power thus becomes the entry point for thinking (1) of human relations as open processes, (2) of actions and their effects as potentially conditioned by uncertainty and thus not subsumable under lawlike regularities, and (3) of cautious and creative political practice beyond the unattainable maxim of achieving control. Perhaps no other concept but power allows for such an entry point linking these three domains. It alone can however not guarantee the theoretical consistency of the links.

\section{Protean power: from causal agency to constitutive process}

The reference definition says that 'Protean power is the effect of actors' improvised and innovative responses to an incalculable environment or their experience of the world as equally uncertain', adding shortly afterwards that 'Protean power has generative effects on the broader context'. ${ }^{14}$ Similarly, in the next chapter, we read that ' $\mathrm{t}]$ he concepts of control and protean power are both about the causal force of agency; in addition, protean power focuses attention to the effects of power. ${ }^{15}$ Indeed, '.. power is not only a cause of empirical patterns but also their effect'. ${ }^{16}$

Protean power is hence cause and effect. Now, the notion of power as both cause and effect is an old problem in the analysis of power that is tied to ideas of causation. If it were fixed to resources or capacities, then they might not always prevail, meaning causes not having 'their' effect - and it would appear odd to call this an exercise of power ('the outcome of the Vietnam War showed US power'). But if one sees power in its effects, then it cannot be used to explain them. 'A won because s/he was powerful (had more power). A is powerful (had more power) because

\footnotetext{
${ }^{10}$ See also Wohlforth 2003.

${ }^{11}$ As in Morgenthau 1948, Waltz 1979. See also the discussion in Guzzini 2020.

${ }^{12}$ For this 'solution', see Barnett and Duvall 2005.

${ }^{13}$ Guzzini 1993.

${ }^{14}$ Seybert and Katzenstein 2018, 10, 11.

${ }^{15}$ Katzenstein and Seybert 2018b, 28.

${ }^{16}$ Seybert and Katzenstein 2018, 13.
} 
s/he won'. The editors are aware of this old risk of introducing tautologies when power is framed in causal terms.

Katzenstein and Seybert propose to avoid the problem in two ways, which may, however, not add up. On the one hand, they relax the efficient causal link assumed in the circle: instead, power is likened to a potential. On the other hand, they rely on the ontological assumption of open (sometimes also complex) social systems. Both meet in a re-definition of causation. But whereas the first strategy leaves power within a causal, if redefined, nexus, the second can do without it. This dual strategy prompts some tension.

The book unpacks the causal path from agency to power. It starts with the idea of uncertainty that prompts a certain type of agency characterized by innovation and improvisation. After first being activated in this way, protean power in turn then affects.... well, what precisely? In order for innovation and improvisation to be related to power, this action must be linked to significant asymmetrical effects. Or, and this is the path taken here, it may affect such asymmetrical effects: '... protean power dynamics make it impossible to anticipate which choices and practices will lead to which outcomes', ${ }^{17}$ that is, it undermines control. Consequently, then, innovation and improvisation are types of action that only give rise to (protean) power if they have the effect of undermining control (power). Protean and control power are thus not just two types of power: protean power manifests itself as a specific incident of power if and only if it undermines control. In this way we reach the circle, which is fundamental to the book: 'Uncertainty breeds protean power and protean power intensifies uncertainty...' 18

Yet, by retaining a causal nexus, albeit relaxing it, many of the links which make the book's thesis attractive cannot be upheld: not all uncertainty breeds improvisation and innovation; not all improvisation and innovation have effects that undermine control; not all effects that undermine control are connected to improvisation and innovation. The circle mentioned above is just one specific path.

We cannot simply assume that any improvisation and innovation will prompt power 'dynamics' (as the book refers to them) that undermine control when innovations can be made in the name of control, a point also made by Green in her chapter. ${ }^{19}$ The book also acknowledges that, in principle, protean power is a unique characteristic not only of the underdog (since they undermine control of the dominant) but also of the dominant, ${ }^{20}$ but the very set-up makes it difficult to untie the two. In the end, we seem to be back to a zero-sum vision between the two: control power is reduced because of protean power; protean power is reduced because of control power.

Reversing the causal direction, not every increase in uncertainty stems from a necessary link to protean power. Not all agency prompted by uncertainty increases uncertainty; not all that increases uncertainty stems from innovation and improvisation. Butterflies need not improvise. It is their routine which potentially has uncertainty-enhancing effects in complex systems.

\footnotetext{
${ }^{17}$ Katzenstein and Seybert 2018b, 36.

${ }^{18}$ Seybert and Katzenstein 2018, 25.

${ }^{19}$ Green 2018, 248, 262.

${ }^{20}$ Katzenstein and Seybert 2018a, 274.
} 
What is fundamental with respect to these two untying moves is to take the ontological assumption of an 'open system' seriously: if the system is open, all forms of agency will have to live with and feed into uncertainty. Established control routines can prompt dynamics that are self-defeating for control. To reduce such dynamics to the effects of protean power does not work. Attributing all diminished control to protean power means attributing all the effects of open systems, even when they are not based on improvisation and innovation, to protean power, which then becomes a hidden and ubiquitous force that is 'verified' whenever we see control slipping. Tracing protean power back from its effects excludes any type of explanation, or even explication, in which power would also lie in agency (a cause), lest it repeats the classic explanatory circle.

Hence, the two ways of avoiding the circle may not add up because an ontology becomes retranslated as an explanatory cause. The book reads at times as if protean power was there to prove that the world is uncertain, indeed that protean power is the reason for its openness. But uncertainty - here: the potentially undermining effects of agency on control - is given by the very ontological assumption of open systems. This attempt to find an empirical path may well be a rhetorical device to persuade the many who do not take the implications of open systems and complexity seriously. It nevertheless overburdens protean power since it is no longer simply a characteristic of an open ontology but also wants to be its empirical cause.

There are, however, passages in the book which refer to power in terms not so much of a theory of action than of a theory of domination, here understood as political order. The idea here is to think of order not from the order-maker down, that is, from 'control power', but through the 'mechanisms' and 'processes' that constitute (not cause) a political order when viewed in an open and complex system. References to a 'process-centered understanding of power', 21 and to power 'dynamics' and 'mechanisms', appear several times in the book. When viewed within such a constituting and processual framework, it is not that these processes are caused by 'power' or are a property of it, as some reifications of 'power' in the book suggest: they literally are what power is about. When Katzenstein and Seybert write that we should ask '... "how do power's mechanisms define the (im)possible, the (im)probable, the natural, the normal"? What matters is the mutability of asymmetries in power that define the field of what is possible, ${ }^{22}$ they speak of power in terms not so much of a reified agency, but of the social order in general. Power as order, that is, 'the field of what is possible', is constituted by these processes, for which the book mainly centres on the agential, not the structural side.

In other words, protean power (and control power) can be identified with a specific order: it summarizes or denotes the asymmetrical effects of social processes in an order characterized by the conditions of open systems. The conceptualization of protean power and control power is hence about neither cause nor effect in this reading. Instead, power summarizes or denotes the variety of paths between the potential of agency and asymmetric effects in governance under the condition of

\footnotetext{
${ }^{21}$ Lockwood and Nelson 2018, 169.

${ }^{22}$ Seybert and Katzenstein 2018, 9.
} 
open systems and uncertainty - it does not explain them. Relating the concept of power to constitutive processes of order avoids the problems we have encountered when trying to tie it to a theory of action in terms of both effect and cause.

\section{Aligning epistemology with ontology: explication, not explanation}

When systems are open and there is no closure, this also has implications for how we conceive of social-science explanations. Another virtue of the book is that it does not eschew thinking in parallel. Thus, aligning epistemology with ontology, ${ }^{23}$ here of open processes, logically leads away from cross-case co-variation to non-efficient causation. All this is necessary because 'complex, open systems undercut the efficacy of past trends and performance as a predictor for outcomes' ${ }^{24} \mathrm{~A}$ processual ontology leads to 'How possibly questions', ${ }^{25}$ which are part of 'broader notions of explication rather than narrower ones of explanation ${ }^{26}$ and chime with critical realist and constructivist positions. ${ }^{27}$

As the empirical chapters in the book show, this openness eschews determinacy, and its sibling probability, for potentiality. However, this form of indeterminacy need not imply arbitrariness, whether of the world or of our explanations. We can retrace the butterfly in the system. The book 'only' invites us to think the social order and our explanations in terms other than regularities and constant conjunctions; it does not suggest randomness. Again, it might not have been fortuitous that the editors took the concept of power as their opening into thinking ontology and epistemology together, since the term 'power' has been closely related to 'causation'. Instead of trying to subsume power under a given understanding of causation, Protean Power redefines causation through a different conceptualization of power. Cause does not inform our thinking about power; power informs our thinking about causation. ${ }^{28}$

\section{The lure (and hubris) of mere strategies of control: a plea for caution when 'embracing uncertainty'}

Some readers may find it curious that the book ends by discussing US politics and foreign policy in just a few pages. Yet, in some sense, they were there all the time. Many of the pages, and surely one of the main motivations for the book, are about how to think world politics when control slips away from all actors, even the USA, which is, however, still in a state of denial. As Susan Strange once put it, it is not that power (as control) just diffuses, as if it were simply picked up in some zerosum game: it 'evaporates' in an order of 'ungovernance. ${ }^{29}$

The neo-conservative answers of the Bush Jr. and Trump administrations, which provides the backdrop to the book, is to double down: the foreign-policy strategy

\footnotetext{
${ }^{23}$ Hall 2003, Kratochwil and Ruggie 1986.

${ }^{24}$ Seybert and Katzenstein 2018, 20.

${ }^{25}$ Katzenstein and Seybert 2018b, 56.

${ }^{26}$ Katzenstein and Seybert 2018a, 268.

${ }^{27}$ See e.g. Kratochwil 2008, Patomäki 1996.

${ }^{28}$ Guzzini 2017.

${ }^{29}$ Strange 1996, 189, 14.
} 
must make sure that control slips as little as possible. Given the present context, that may well mean that cooperative gains are sacrificed in a strategy of 'relative loss'. Any resistance to US interests may make everyone worse off but everyone more than the USA. The US blackmails friends and foes alike by mobilizing not only its military might, but in particular its still 'exorbitant privilege' that comes from running the main world currency. As 'Nixon's Treasury secretary John Connolly put it to his international peers, with characteristic subtly, "the dollar is our currency but it is your problem". " The financial crisis of 2008 may have undermined US power by undercutting the legitimacy of the order, ${ }^{31}$ but it has also weakened any attempt actually to change it by re-conducting the USA to its central role. ${ }^{32}$ Stanley Hoffmann could still address a bipartisan expert system by positing US primacy and the world order as alternatives. ${ }^{33}$ In a situation of potentially declining control, the neo-conservative answer is that US primacy is the world order. The neo-conservative problem of international governance would hence not be that there is too much US quest for control, but that there can never be enough.

Protean Power argues that this quest is a lure: it can ultimately not succeed in a world of unknown unknowns. Just as scientists are well advised to fundamentally include the contingency of processes in their explanations, practitioners should heed a revised piece of realist advice to caution: '.. in the domain of unknown unknowns ... caution or impetuousness are the proper response'. ${ }^{34}$ Anything else is just classic hubris against which practitioners have cautioned us time and time again. '[D] ominant actors are not masters of the universe... [w]e should be prepared to accept a world in which protean power plays an important part', ${ }^{35}$ and 'where uncertainty creates, in contrast, a premium on judgment'. ${ }^{36}$

Yet, the book is aware that embracing the substantial uncertainty of unknown unknowns does not necessarily lead to such caution. Trump's foreign policy can be seen precisely as deliberately producing uncertainties in 'a bet on the success of unrestricted, unilateral control power and the protean power dynamics (sic) creating heightened volatility and unpredictability. ${ }^{37}$

Nor is it clear how one can argue that this is an 'improper' strategy when faced with uncertainty. Good judgement (or practical knowledge) is an old, but hitherto slippery maxim. If it is true that control is possible, but not everywhere, and that improvisation and innovation can be helpful in any case, why not combine the two and make sure the worst case does not arise? After all, Rumsfeld's 'unknown unknowns' were not just a reflection of paranoia, but the worst-case scenario thought through to its logical end point. In return, it justifies a heightened sense of the worst-case scenario which makes even the USA, which trumps anyone else in military terms, feel insecure: there is always something that could happen. One needs to address all possible threats. And, in this endless quest, the only answer

\footnotetext{
${ }^{30}$ Cited in Kirshner 2014, 29.

${ }^{31}$ Kirshner 2014.

${ }^{32}$ Helleiner 2014.

${ }^{33}$ Hoffmann 1978.

${ }^{34}$ Katzenstein and Seybert 2018a, 288.

${ }^{35}$ Katzenstein and Seybert 2018b, 39, 40.

${ }^{36}$ Abdelal 2018, 151.

${ }^{37}$ Katzenstein and Seybert 2018a, 298.
} 
is more (control power) of the same. One implication of this strategy as informed by 'unknown unknowns' is the re-militarization of politics (the reversal of Clausewitz) by turning power into an end in itself: primacy for the sake of it. If mere risk is calculable and could be used to find compensations and common gains, uncertainty is incalculable, which can invite caution just as much as its opposite.

Indeed, in democratic politics, it is usually a self-defeating strategy to say that we are deeply uncertain and need to be cautious unless this is coupled with attempts to take 'back control', as the Brexit campaign reminded us. The popular sovereign wants answers, not expressions of powerlessness. Protean power as the uncertainty increasing the effects of agency alone will not be a solution. Control power may be a lure, but, for politicians, reducing uncertainty may be the only legitimate game in town.

Hence, the classic way to ensure that caution is facing the ontological uncertainty of an open world is reflexivity of the adverse effects the quest for absolute control would have, like the self-fulfilling prophecies of power politics. That judgement, however, is no longer easy, since in a world of unknown unknowns, we basically do not know all the effects, adverse or not. Insisting on the 'unknown unknowns' may unwillingly contribute to the strategy of desperately translating them into risk situations of worst cases, where the 'worst' is defined by a certain normative system and has a price tag attached. Improvisation and innovation would simply perfect the control paranoia. When Marcus Klingberg, an Israeli who had been caught spying for the USSR, became eligible for 'full release, Israel's defense security service, Malmab, demanded that Klingberg be kept under close scrutiny. In a submission to the court, Malmab claimed Klingberg's "mind contains information he is not aware of". Klingberg's lawyers were stumped: there was no defense against charges about things he did not know that he knew'. ${ }^{38}$ Perhaps here too the ontological, explanatory and practical domains of power analysis do not easily meet, or, at least, not in the desired manner.

Acknowledgements. My thanks go to Peter Katzenstein for the multiple exchanges we had on circulatory and then Protean Power, in correspondence and then in person when I joined teaching (for very short) Jill Frank's and his seminar on 'Power' at Cornell University during Fall 2016. And to the late Lucia Seybert whose ideas have made the book and this Symposium possible.

\section{References}

Abdelal, Rawi. 2018. "Firms in Firmament: Hydrocarbons and the Circulation of Power." In Protean Power: Exploring the Uncertain and Unexpected in World Politics, edited by Peter J. Katzenstein and Lucia A. Seybert, 147-65. Cambridge: Cambridge University Press.

Adler, Emanuel. 2019. World Ordering: A Social Theory of Cognitive Evolution. Cambridge: Cambridge University Press.

Albert, Mathias. 2016. A Theory of World Politics. Cambridge: Cambridge University Press.

Barnett, Michael, and Raymond Duvall. 2005. "Power in International Politics." International Organization 59 (1): 39-75.

Connolly, William E. 1974. The Terms of Political Discourse. 2nd edn. Oxford: Martin Robertson.

Frei, Daniel. 1969. "Vom Mass der Macht. Überlegungen zum Grundproblem der Internationalen Beziehungen." Schweizer Monatshefte 49 (7): 642-54.

\footnotetext{
${ }^{38}$ Pringle 2014.
} 
Green, Jessica F. 2018. "From Green to REDD: Protean Power and the Politics of Carbon Sinks." In Protean Power: Exploring the Uncertain and Unexpected in World Politics, edited by Peter J. Katzenstein and Lucia A. Seybert, 246-63. Cambridge: Cambridge University Press.

Guzzini, Stefano. 1993. "Structural Power: The Limits of Neorealist Power Analysis." International Organization 47 (3): 443-78.

Guzzini, Stefano. 2005. "The Concept of Power: A Constructivist Analysis.” Millennium: Journal of International Studies 33 (3): 495-522.

Guzzini, Stefano. 2009. "On the Measure of Power and the Power of Measure." In DIIS Working Papers 28/ 2009. Copenhagen: Danish Institute for International Studies, 18pp.

Guzzini, Stefano. 2013a. "The Ends of International Relations Theory: Stages of Reflexivity and Modes of Theorizing." European Journal of International Relations 19 (3): 521-41.

Guzzini, Stefano. 2013b. Power, Realism and Constructivism. Abingdon: Routledge.

Guzzini, Stefano. 2017. "Power and Cause." Journal of International Relations and Development 20 (4): 737-59.

Guzzini, Stefano. 2020. "Embrace IR Anxieties (or, Morgenthau's Approach to Power, and the Challenge of Combining the Three Domains of IR Theorizing)." International Studies Review 22 (2): 268-88.

Hall, Peter A. 2003. "Aligning Ontology and Methodology in Comparative Research." In Comparative Historical Analysis in Social Sciences, edited by James Mahoney and Dietrich Rueschemeyer, 373-404. Cambridge: Cambridge University Press.

Helleiner, Eric. 2014. The Status Quo Crisis: Global Financial Governance after the 2008 Meltdown. Oxford: Oxford University Press.

Hoffmann, Stanley. 1978. Primacy or World Order: American Foreign Policy since the Cold War. New York: McGraw Hill.

Katzenstein, Peter J., and Lucia A. Seybert. 2018a. "Power Complexities and Political Theory." In Protean Power: Exploring the Uncertain and Unexpected in World Politics, edited by Peter J. Katzenstein and Lucia A. Seybert, 267-301. Cambridge: Cambridge University Press.

Katzenstein, Peter J., and Lucia A. Seybert. 2018b. “Uncertainty, Risk, Power and the Limits of International Relations Theory." In Protean Power: Exploring the Uncertain and Unexpected in World Politics, edited by Peter J. Katzenstein and Lucia A. Seybert, 27-56. Cambridge: Cambridge University Press.

Kirshner, Jonathan. 2014. American Power after the Financial Crisis. Ithaca, NY: Cornell University Press. Kratochwil, Friedrich. 2008. "Constructivism: What it is (not) and How it Matters." In Approaches and Methodologies in the Social Sciences, edited by Donatella della Porta and Michael Keating, 80-98. Cambridge: Cambridge University Press.

Kratochwil, Friedrich. 2018. Praxis: On Acting and Knowing. Cambridge: Cambridge University Press.

Kratochwil, Friedrich, and John Gerard Ruggie. 1986. "International Organization: A State of the Art on an Art of the State." International Organization 40 (4): 753-75.

Lockwood, Erin, and Stephen C. Nelson. 2018. "Incomplete Control: The Circulation of Power in Finance." In Protean Power: Exploring the Uncertain and Unexpected in World Politics, edited by Peter J. Katzenstein and Lucia A. Seybert, 166-87. Cambridge: Cambridge University Press.

Lukes, Steven. 1974. Power: A Radical View. London: Macmillan.

Morgenthau, Hans J. 1948. Politics Among Nations: The Struggle for Power and Peace. New York: Knopf. Nye Jr., Joseph S. 2004. Soft Power: The Means to Success in World Politics. New York: Public Affairs.

Nye Jr., Joseph S. 2007. "Notes for a Soft Power Research Agenda." In Power in World Politics, edited by Felix Berenskoetter and M. J. Williams, 162-72. London, New York: Routledge.

Patomäki, Heikki. 1996. "How to Tell Better Stories about World Politics." European Journal of International Relations 2 (1): 105-33.

Pringle, Peter. 2014. "Marcus Klingberg: The Spy Who Knew Too Much." The Observer, 27 April 2014. Available at: https://www.theguardian.com/world/2014/apr/27/marcus-klingberg-soviet-spy-kgb. Accessed 27 April 2014.

Qin, Yaqing. 2018. A Relational Theory of World Politics. Cambridge: Cambridge University Press.

Seybert, Lucia A., and Peter J. Katzenstein. 2018. "Protean Power and Control Power: Conceptual Analysis." In Protean Power: Exploring the Uncertain and Unexpected in World Politics, edited by Peter J. Katzenstein and Lucia A. Seybert, 3-26. Cambridge: Cambridge University Press.

Strange, Susan. 1996. The Retreat of the State: The Diffusion of Power in the World Economy. Cambridge: Cambridge University Press. 
Waltz, Kenneth N. 1979. Theory of International Politics. Reading: Addison-Wesley.

Weber, Cynthia. 2016. Queer International Relations: Sovereignty, Sexuality, and the Will to Knowledge. Oxford: Oxford University Press.

Wendt, Alexander. 2015. Quantum Mind and Social Science: Unifying Physical and Social Ontology. Cambridge: Cambridge University Press.

Wohlforth, William C. 2003. "Measuring Power - and the Power of Theories." In Realism and the Balance of Power: A new Debate, edited by John A. Vasquez and Colin Elman, 250-65. Upper Saddle River, NJ: Prentice Hall.

Cite this article: Guzzini, S. 2020. "Protean power as a plea for an open social ontology, non-efficient causal explanations, and cautious political practice." International Theory 12, 449-458, doi:10.1017/ S1752971920000287 